\title{
AGRICULTURAL PERSPECTIVES OF CLIMATE CHANGE INDUCED DISASTERS IN DOTI, NEPAL
}

\author{
Narayan Paudyal ${ }^{1}$, Ram B. Khadka ${ }^{2}$ and Ranjana Khadka ${ }^{3}$
}

\begin{abstract}
Natural disasters are among the major risk factors in aggravating human and livestock lifes as well as agricultural production in most of the developing and poor countries. A community level survey was conducted in Doti district to assess the rural communities' perception towards the disasters induced by climate change in agriculture and livestock production and productivity. Discussions with two focal groups, at village level and with district based stakeholders revealed that there is a conceptual difference between the perception of disasters at the government level and the farmers' level. Most of the farmers have realized the major disasters of slow onset type (drought and famine) to be more common than the rapid onset type (landslides and floods). There has been a change in the cropping pattern with decreased winter rain and short monsoon rain. The local communities have suffered due to drought which has lead to fewer water holes for animals and less water for irrigation. Farmers have gradually decreased the number of larger ruminants like cattle and buffalo and are inclined towards smaller animals like sheep and goat. Animal diseases as well as insects-pests of crops are also on the rise.
\end{abstract}

Key Words: Agriculture, Livestock, Climate change, Disaster

\section{INTRODUCTION}

Agriculture remains Nepal's principal economic activity, employing over $65 \%$ of the population. Only $20 \%$ of the total area is cultivable; another $29 \%$ is forest (MOAC, 2011). Rice, wheat and maize are the main cereal crops mostly produced in the Terai region which constitutes $43 \%$ of the total cultivated land (MOAC, 2011). Majority of the farmers are reliant on rainwater for irrigation, as the country lacks major facilities for artificial irrigation. On average, about $65 \%$ of the total cultivated land is rainfed (MOAC, 2011). Reduced water availability during dry periods could exacerbate agricultural water needs, as an estimated $64 \%$ of the country's farmers rely on water from rains of the monsoons. Planting and harvesting seasons have been slowly changing in Nepal, due to the shifting monsoon, and these shifts are likely to become more erratic under a changing climate. Over $80 \%$ of Nepal's managed water is used for irrigation and $38 \%$ of the country's agricultural land is irrigated. Even high-input, irrigated wheat, maize, and sorghum yields show significant decreases in northwest Nepal under a changing climate in the $2020 \mathrm{~s},-51.24 \%,-30.7 \%$, and $-25.93 \%$, respectively. Projected rainfall decrease during the winter could impact winter and spring yields, while projected temperature increases are likely to reduce maize and wheat yields (MOAC, 2011).

\footnotetext{
${ }^{1}$ Scientist, Veterinary, NARC, RARS, Khajura, Banke, email: narayan.paudyal@narc.gov.np

${ }^{2}$ Scientist, Plant Pathology, NARC, RARS, Khajura, Banke

${ }^{3}$ Researcher, IAAS/TU
} 
Nepal is highly vulnerable to various types of disasters like floods, landslides, earthquake, fire, epidemics, and effects of climate change. In addition, the country also has encountered new types of disasters like 'avian influenza' (bird flu) pandemics, industrial accidents, explosions of improvised explosive devices, road accidents, and poisoning related cases. Out of the 75 districts in the country, 49 are prone to floods and/or landslides, 23 to wildfires, and one to windstorms. A total of 64 out of 75 districts are prone to disasters of some type (Dangal, 2009).

There are various literatures that classify the hazards based on their impact they put on the environment and human life. This is a dynamic measure with varying degree of flexibility across the globe but the most suitable one for our Nepalese context can be the one given by Bhandari and Malakar (2009) is as given below.

- High frequency hazard: One that has occurred at least twice in 5 years or 3 times in 10 years. The occurrence of the hazard appears to have increased in recent decades.

- Medium frequency hazard: One that has occurred 1 to 2 times in the last 5 years or at least twice in the past decade.

- Low frequency hazard: Hazards that have occurred only once in the last 10 years or more.

- Highly severe hazard: One that has caused severe damage in past events.

- Medium severe hazard: One that has caused moderate damage in past events.

- Low severe hazard: One that has not created a situation where external support has been sought. The affected family or community has been able to cope and manage using their own capacities and resources.

\section{PROBLEM STATEMENT}

The country falls in the top 20th list of the most multi-hazard prone countries in the world (Dangal, 2009). Among 200 countries, Nepal ranks 4th, 11th and 30th with regard to relative vulnerability to climate change, earthquake and flood hazards respectively (Dangal, 2009). Other major disasters in Nepal are landslide, fire, drought, epidemic, storm, hailstorm, avalanches and glaciar lake outburst flood (GLOF). Disaster risk reduction and climate change adaptation have become national priority and being institutionalized to support sustainable development in Nepal (Dangal, 2009).

Disaster risk reduction is understood as the "concept and practice of reducing disaster risks through systematic efforts to analyse and manage the causal factors of disasters, including through reduced exposure to hazards, lessened vulnerability of people and property, wise management of land and the environment, and improved preparedness for adverse events"(UNISDR. 2009). While distinct in scope, disaster risk reduction and climate change adaptation (CCA) share a common concern over climate-related extreme events, and in the agriculture sector they both aim to build resilient livelihoods. Frequently, disasters combine with other factors and underlying vulnerabilities to produce food insecurity and hunger. Climate change is a multiplier of risk by increasing the number and scale of extreme climate-related events such as drought and floods. Disaster risks and 
climate change both impact negatively and in similar ways on agriculture and both threaten to increase hunger over time. In addition there is growing probability of 'simultaneous crises where different hazards occur at the same time, 'sequential crisis' where hazards trigger cascading disasters in a range of interlocked systems and 'synchronous failures' where different risks converge and interact. The prime objective of this study was to evaluate the understanding of the community to the climate change and its consequences (disasters) and its relation to the agricultural systems including the livestock.

\section{METHODOLOGY}

Community-based and district-based stakeholders were surveyed using prestructured questionnaire format to identify the disaster situation and response system in middle hilly region of Doti. Two focal group discussions were held at two different localities with the senior and experienced people at the community level and district based stakeholder. We surveyed people over 50 years of age. We could not find any women above 50 years age who wanted or were able to participate in the research. Two communities were surveyed- Ghog Tal (30 HH) and Dewarmandu $(60 \mathrm{HH})$, but target community would be the whole VDC (1100 $\mathrm{HHs}$, about 6,500 people). These communities were selected based on the DADO, Doti 2010, report that these two areas are the most food insecure as well as hazard prone areas of the district. On top of these the selected areas are physically inaccessible than other areas meaning that they had no exposure to measures intended for hazard minimization as given by the district based INGOs and NGOs. The major segment of the inhabitants in the VDC are Chhetris (around $56 \%$ ), with a significant number of Dalits (lower caste, around $27 \%$ ), some Janajatis (ethnic/tribal groups, 10\%) and high caste (Brahmin/Bahun, 6\%). At the district level, key informant interviews with district level stakeholders were carried out. District based stakeholders involved in the study were the District Development Committee (DDC), CDO, LDO, DLSO, DADO, The Red Cross, Nepal Army, Nepal Police and Armed Police Force, located within the district. The data obtained were analysed with simple descriptive statistics using MS Excel vs 2007 software.

\section{RESULTS AND DISCUSSIONS}

The data on current water availability was different according to the locality. Respondents said that irrigation is not sufficient for the cultivation of crops and vegetables. Drinking water was currently available in the communities surveyed and was just sufficient for current consumption needs. The communities are worried that their water supplies will not be sustainable. The people surveyed said that any drinking water project only lasts for 10-15 years because water sources (springs) are drying up.

The community members said that the main hazards were drought in winter and late onset and early cessation of monsoon rainfall. All the farmers said that drought is the major hazard causing difficulties in their lives. Similarly soil erosion/landslides in monsoon are reported as another problem in this area 
however the respondents could not quantify magnitude but all of the respondents agreed that poor vegetation on the hills and tilling the 'khoriyas' for maize and millet is responsible for the landslides. There is no rainfall in winter season and late onset of monsoon and more rainfall (of sudden onset for short time but with larger water drops and causing debris flow in the barren hillside) per unit time is causing the major problem in their livelihoods. Drought is causing losses in areas of the district where irrigation is not available. $90 \%$ of the people in the district depend on agriculture and only $6 \%$ of the cultivated land is irrigated (DADO Doti, 2009, 2010). The major hazards as identified by the community are presented in Figure 1.

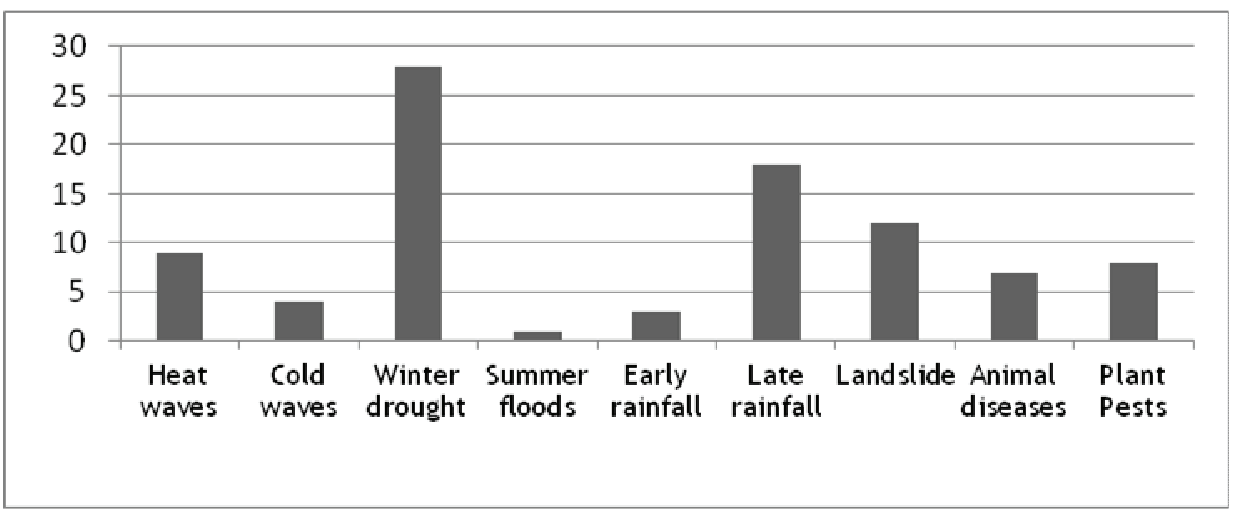

Figure 1. Major hazards as identified by the community

In Nepal, most of the parts are in the grip of drought-like condition from the end of March till the monsoon arrives next in June, but the districts like Manang and Mustang in the Trans-Himalayan region are extremely dry throughout the year and the Terai and western hills are more frequently affected than other regions (The World Bank, 2011). Drought results in crop failures and famine, both during the monsoon season and rest of the year, when winter crops are sown. About 5,000 families living in pockets in the hills and terai are badly affected by drought each year (MoHA, 2009). A general declining precipitation trend is observed in most of the far-western and northern part of western, central and eastern Nepal (MoAC, 2011) which positively correlates with the general perception of the community in the study areas where they identified drought as the major hazard.

The respondents informed that there were two main cropping seasons in their locality winter (wheat, barley) and summer (rice, maize, millet; millet being an alternative to rice), with some vegetables grown in between (including potato). Farmers have devised and are practicing their own local adaptation strategy for mitigating the adverse effects of the drought. In case of late onset of monsoon rains, the farmers sow millet instead of rice; millet gives a lower yield as compared to rice and is not highly valued by the communities (although it does have high nutritional value!), so as to cope with the food insecurity that arises due to failure of rice crop (Figure 2). In absence of winter rains, the wheat (barley is not affected, unfortunately this is mostly used as animal feed!) crop also fails. 
Then there will only be one main cropping season thus meaning that an alternative source of income has to be searched for by the affected households.

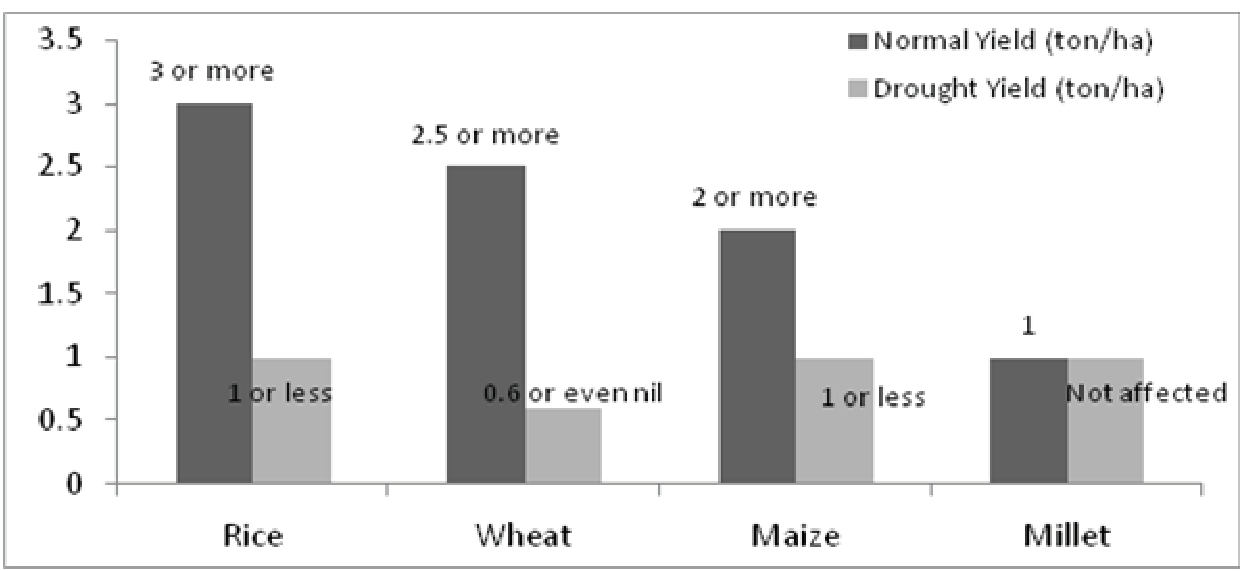

Figure 2. Harvest comparison in normal and drought period, for various cereal crops

A recent report states that resource poor farmers in Nepal developed crop related innovations in response to more frequent flooding, changes in monsoon timing, and increased incidences of landslides. In drier areas, farmers now plant garlic at the base of cut paddy, mulched with paddy straw, to minimize the use of irrigation water, and to save on tillage costs. To produce more food, some farmers grow millet in winter after potato crop rather than leaving the fields fallow. All the respondents agreed that in case of failure of crops or reduced food and economic security at home, men and youth migrate to India for work or sometimes to the terai cities of Nepalgunj, Dhangadi and Mahendranagar to work as labourers or anything available where they stay for several months. As the men undertake seasonal migration to nearby towns to seek work, the women, young boys and girls are left to cope with variable climate and management of farm. Farmers shared their experiences that their daughter in laws, wives and daughters had to drive the oxen plough to till their fields for crop cultivation. They need to travel long distances to collect firewood and water for both household use and livestock. Highly variable and unpredictable climatic conditions have lead to food shortages at the household level and thus children and elderly are most likely affected by under nourishment (MoAC, 2011).

Respondents $(77 \%)$ reported that natural resources like water sources are drying day by day due to the drought resulting lowering of vegetations in the hills thereby affecting badly on the farmer's livestock business. The pasture and fodder resources are declining thus people have started to change the livestock husbandry pattern from large animals like cow and buffalo to smaller animals like sheep and goat and the cumulative number of livestock owned has reduced as reflected in Figure 3. 


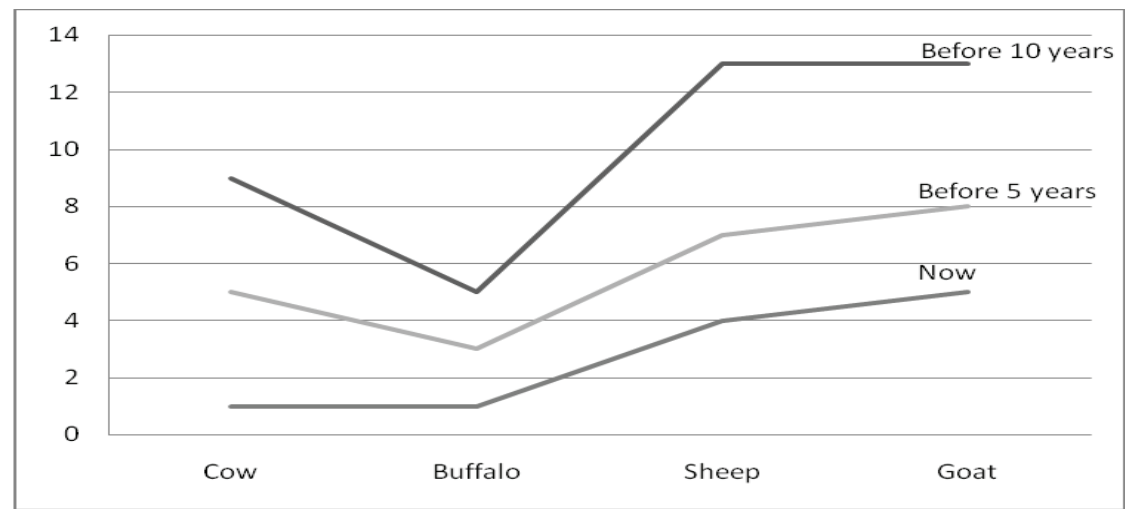

Figure 3. Trend of livestock ownership

Some farmers in other locality have started even commercial broiler farming (small scale 100-500 birds) but none of the participants were involved in such activities. Lack of grass fodder in the meadows means the farmer are more dependent on tree fodder and forest resources, which results in more trees dying, reduced slope cover (thus increasing risks of soil erosion and landslide), and deforestation. Deforestation means that the task of obtaining firewood is increased - again a task that is mostly done by women and girls-and exposes slopes to soil erosion and desertification.

\section{DISASTER FREQUENCY}

Respondents of this study reported that in seven of the last ten years there has been no normal winter rainfall, and in five of the last ten years monsoon was late in summer. The respondents could not remember such a long drought before. All respondents reported that in last ten years, winter rain for the wheat crop has only occurred in sufficient amounts three times (including year 2010). During this time they have not seen snowfall in the winter in their locality, whereas up to 15 years ago snow regularly fell upto 3 feet thick. The low snowfall has a very bad impact in wheat production. In the monsoon season crop yields are reduced due to lack of water for growth and a shortened growing season, since people have to sow their crops later or revert to a lower value and production crop such as millet. They related experience of big famine in $1966 \mathrm{AD}$ which was due to hailstorms during both rice and wheat harvesting time, thereby causing famine. It had lead to a total loss of harvest and the subsequent migration of people to the flat southern plains in search of food. There was no road linkage and the then situation made people very vulnerable. Respondents felt that such a famine is now occurring each year in their area due to the erratic and untimely rainfall. Under normal rain-fed conditions, there would be enough food production for 10-11 months of the year, but under the drought conditions there is only enough production for 6-8 months. For the remaining months they depend on external food sources. This is managed either by the help of aid agencies (WFP, FAO, etc. are resourcing food for work programmes in the vulnerable communities), or by remittances earned through the seasonal migration of labour from their families. Therefore it is probably a little easier to manage the situation now compared to 1966 due to the 
development of road linkages and easy access to food grains from external sources due to the increased cash income.

\section{Impacts of hazards on natural resources and livelihood}

The consequences of drought are most relevant as cited by the local community in descending order were water scarcity as springs dry up; reduced winter rainfall; reduction in irrigation facilities; water holes for animal drying up; interference with monsoon cycle; increased crop pests and diseases thus reducing production; decreased livestock production and productivity (problems of infertility and parasites). All respondents in this study had a common understanding that their vulnerability to the drought could be reduced if they have sufficient knowledge on climate change and adaptive farming in the new context. Similarly, the impact of long drought could be reduced by the construction of suitable irrigation systems in their community. The respondents reported that the traditional water supply systems were not working properly, but provided little analysis beyond this. Traditional water systems are springs (referred to as naulo, kuwa locally), their water collecting structure and distribution pipes and points, and traditional canals (which are not cemented). Users suggested that these are not working properly because the structures are poor and the water sources are not sufficient. Not only has the drought impacted the agricultural practices, it has even put social harmony at misbalance. The focus group discussion at the community level revealed that in 2008 one VDC wanted to bring a water pipe across the edge of another VDC which refused to give permission unless they also got to use the water supply (a water tap). They threatened to cut the pipe. The elderly people had never heard such conflict of interests in their entire life! The location also contributed to vulnerability, as villages tended to be located quite high up on hill slopes and ridges. National reports have that in 2009 , the summer monsoon was delayed and weak- therefore the transplanting of paddy was delayed in most parts of the country, and in the same year, flood occurred in western Nepal during the harvesting period causing a damage of 20 to $25 \%$ on paddy production (MoAC, 2011).

Much of the population reliant on rain fed agriculture is vulnerable to localized drought and more variable precipitation in terms of form, timing and intensity. With increased intensity of summer monsoon rain events, the risk of flash flooding, erosion and landslides will be increased. With warmer winters, particularly at higher altitudes, less precipitation may fall as snow, further accelerating glacial retreat but also reducing soil moisture and accelerating erosion, and therefore impacting on winter crops (MoAC, 2011).

Soil degradation through flash floods (debris flows) during intense heavy rainfall, and excess drying and bleaching during the dry season; and finally increased threat of landslides because of increased intensity of rainfall during monsoon though are not the direct impacts of droughts, are seen secondary to drought due to lack of soil moisture for proper vegetation growth on slopes of hills thus increasing the risk of these events. The drought has caused a reduction in the availability of fodder grasses and therefore pressure on forest trees is increasing in 
order to sustain the livestock business in the farming households. Livestock have become more vulnerable to diseases from warmer areas as temperatures increase. Newer diseases and increase worm infestation are the major problems with an increase in the skin infections too (DLSO, Doti 2010). Higher temperatures speed up the lifecycle of some pests and disease vector insects so that populations grow faster. Due to lack of awareness, destructive harvesting of the forest grass and trees for green fodder has been going on and hence the forest is being degraded. This in turn results in vulnerability of the soil to erosion and farmed slopes landslides. Even where there are trees, they have been excessively looped for fodder and hence not are able to retain the soil holding capacity.Smallholder farmers are the most vulnerable to the predicted impacts of climate change. Climate change is most likely to have an increasing negative effect on the mitigation capacities, for example irrigation as springs dry up and an increased network of irrigation canal has an increased likelihood of being damaged by even minor soil erosions landslides. Livestock may become vulnerable to diseases from warmer areas as temperatures increase, and increased intensity of rainfall on ever denuded slopes is likely to increase the incidence of landslides in the future, further depleting crop production through loss of arable land.

\section{LOCAL ADPTATION CAPACITY}

Farmers have identified the varieties having the capacity to resist drought, cold temperatures or frost. An example was cited in community based focus group discussion that the farmers since three or four years back have started planting potatoes in a diversity of altitudes and terrains thus contributing to the conservation of potato varieties and also ensuring that the crops survive in some locations even when they fail in others so that the food insecurity could be minimized.

An extensive number of technologies and practices are implemented to reduce the vulnerability and build the resilience of farming systems. Crop diversification, crop insurance schemes, drought or flood tolerant crop varieties, hazard-proof grain storage facilities and livestock shelters, strategic fodder reserves, biosecurity of animal production systems, resilient animal breeding, and water reserves to buffer droughts are some of the many examples (FAO, 2011). Some farming communities are already undertaking several local coping strategies. These include changing crops such as growing vegetables instead of grain crops, planning for short duration and low water requiring crops, diversification of farm enterprises, rain water harvesting and erosion control measures (MoAC, 2011)

\section{Individual capacity}

Local knowledge and skills: People know where springs usually emerge and what locations look likely to be a new water source. People are familiar with local pests and diseases, and know about local cures. They can quickly identify new or unfamiliar diseases and pests and seek help, or they can try local remedies. Local skills to build and/or maintain irrigation canals exist in the communities- these can be built upon and used to train others. 
Labour: People are willing to and are able to offer their own labour to a community effort to reduce vulnerability, or help others affected by a disaster (rapid or slow onset) in case required.

\section{Social capacity}

There are social structures and systems of leadership and ways that things happen. These can be tapped into in order to mobilise the communities when they are in dire situation. Since these societies in hills of far western Nepal are dominated by men, and women are commonly in the majority while men work abroad, female headed structures and systems are developed.

\section{Physical capacity}

Irrigation canals and improved water supply systems (with reservoirs and pipes) made with the aid of various INGOs in their locality have proved very useful in reducing vulnerability to water shortages. Rain water harvesting has also been very successful in other parts of the country for mitigating the adverse effects of water scarcity. It is reported that over 11000 such systems are in use in the hill districts of Nepal. A survey has reported that around $78 \%$ of the users were satisfied with the service and some 47,000 people are getting a satisfactory service out of rainwater harvesting, often in water stress areas (uphill areas in Kaski, Tanhu, and Doti)(MoPPW, 2009) The stored water could be used for animals, drip irrigation and household purposes. Studies in Syangja and Tanahun have shown that the most potential use of harvested rainwater was for the livestock (74.26\%) use followed by washing utensils (68.32\%) and household cleaning and sanitation purpose (53.47\%) (Dahal et al., 2010)

\section{Natural capacity}

Wood and stone is locally available, although in short supply. Organic manure is available from animals and gathering fallen leaves from the remaining forest. Commodities that were previously discarded, such as maize stalks, are being used for alternative uses such as mulching and firewood. Rearing of smaller livestock like sheep and goats that need less fodder is seen to be more beneficial as compared to larger ruminants like cows and buffaloes which need more fodder. They have increased the use of non conventional feed stuffs (such as crop by products of legumes and rapeseed) in livestock rearing thus reducing the food competition of livestock with humans.

\section{Economic capacity}

Economic migration, searching for off farm income generation activities, has been occurring for some years as a coping strategy in the study area. Respondents could not provide ample evidence that significant remittances are occurring though around $65 \%$ of the households own at least a cellular mobile phone. As a result of male migration not only are female's workloads increasing, but also the water scarcity and deforestation that result from climate variability necessitate that 
women walk longer distances in search of water, fuel wood, and fodder (Synnott, 2012).

Most families have some farm animals which can provide a means to raise capital rapidly if necessary. However, fodder is a limiting factor, and animal husbandry can be expensive, especially if sickness strikes. Farmers have been found keen to adopt improved crop varieties and animal husbandry as well as veterinary initiatives to build on this capacity as can be seen from the use of improved varieties of crops and anthelmintic drugs provided by some donor agencies like UMN, FAO and Practical Action.

\section{CONCLUSIONS}

The results show that there are localized effects of climate change in the study site with most visible outcomes being the drought. The disaster risk as a consequence of climate change is concentrated on droughts, famines, landslides, crop and livestock diseases. While people have clearly stated feelings the consequences of climate change, they are equally worried that their risk minimization strategies may not be sufficient. In order to cope with current stresses to livelihood, farmers have adopted several strategies for coping with climate change and food insecurity, many of which are unsustainable over the long term. These include incorporation of agro-ecology and agro-forestry into current farming systems, improvement of water management, livelihood diversification, and climate risk management. Increasing environmental degradation reduces the availability of goods and services to local communities, shrinks economic opportunities and livelihood options, and ultimately contributes to greater food insecurity and hunger.

Long term reductions in water supply, declining yields of staple food crops, roads and other infrastructures, vegetation changes and new challenges to crop, and livestock health are all examples of anticipated impacts of climate change that need planning immediately. As the climate has changed with unpredictable rainfall, evidences of increasing trend in climate related disasters have been observed resulting from droughts, landslides and floods. The shifting of temperature regime towards higher elevations is likely to threaten the health of the people, livestock and crops with pests and diseases which were not prevalent there earlier.

The actions and strategies to build communities' ability to adapt to climate change can and must be undertaken before "the last crops have failed". Sharing experiences, obstacles and positive initiatives with other communities and development policy makers must be an integral part of national adaptation strategies. Government must allocate resources to prepare for the inevitable impacts of climate change and develop adaptation activities and skills within the communities so that agricultural production does not decline due to high or inadequate rainfall, and onset of drought; checking hazards in agricultural production emanating from the use of insecticides; and treatment and control of epidemics in livestock. 


\section{REFERENCES}

Bhandari, D., and Y. Malakar, 2009. Practical approaches on community based disaster management planning, Working paper no 1/DRRCC/IR/PA/NEP "Mainstreaming Livelihood Centred Approaches to DRR", Project of Practical Action with funding support from DFID. Practical Action in Nepal, Pandol Marg, Kathmandu, Nepal

Bhandari, G.P., S. Gurung, M. Dhimal, C.L. Bhusal, 2012. Climate change and occurrence of diarrheal diseases: evolving facts from Nepal. Journal of Nepal Health Research Council, 10(22):181-6.

DADO, 2010. Annual Report, District Agriculture Development Office, Doti

Dahal, R, J. Ban, S. Makaju, R.S Shrestha and N. Dwa, 2010. Rainwater harvesting (RWH) in Nepal: A case study on social acceptability and performance evaluation of RWH schemes implemented in Syangja and Tanahun districts. Study Report prepared for partial fulfillment of final year project of the degree of Bachelors in Civil Engineering in the Institute of Engineering in Western Regional Campus, Pokhara, Nepal.

Dangal, R., 2009. Country Profile- Nepal, Disaster risk management: policies and practices in Nepal. Available online at http://www.adrc.asia/countryreport/ NPL/2011/FY2011B_NPL_CR.pdf, retrieved on 13th March 2013.

DLSO, 2010. Annual Report, District Livestock Service Office, Doti

FAO, 2011. Resilient livelihoods - disaster risk reduction for food and nutrition security framework programme. Available online at http://www.fao.org/docrep/015/i2540e/i2540e00.pdf, retrieved on 7th March, 2013.

MoAC, 2011. Priority framework for action climate change adaptation and disaster risk management in agriculture. Government of Nepal, Ministry of Agriculture and Cooperatives, Singhadurbar, Kathmandu, Nepal.

MoPP, 2009 Governement of Nepal, Ministry of Physaical Planning and Works, Singhadurbar, Kathamndu, Nepal. Available online at http://www.moppw.gov.np/pdf/Status_of_RWH_in_Nepal.pdf, retrieved on 9th march, 2013

Practical Action, 2013. Policy Briefing: Promoting adaptation to climate change in Nepal. Available online at practicalaction.org/media/download/5754, retrieved on 9th march 2013

Prolinova, 2011. What can local innovation contribute to adaptation to climate change? Report of Prolinova International Scretariat, ETC Foundation, Luesden, The Netherlands. Available online at

http://www.prolinnova.net/sites/default/files/documents/thematic_pages/climate_chang e_pid/2011/prolinnova_policy_brief_climate_change_june_2011_lowres.pdf, retrieved on 11th March, 2013.

Synnott, P., 2012. Climate change, agriculture, and food security in Nepal- developing adaptation atrategies and cultivating resilience. Report prepared for Mercy Corps Nepal. Available at http://nepal.mercycorps.org/pdf/climate-change-agriculture-andfood-security-in-nepal.pdf, retrieved on 7th March, 2013.

The World Bank, 2011. Climate risk and adaptation country profile, Nepal. The World Bank Group, Washington DC, USA, Available online at http://sdwebx.worldbank.org/climateportalb/doc/GFDRRCountryProfiles/wb_gfdrr_cli mate_change_country_profile_for_NPL.pdf, retrieved on 7th March, 2013.

UNISDR, 2009. UNISDR Terminology on Disaster Risk Reduction. United Nations International Strategy for Disaster Reduction, Available online at http://www.unisdr.org/files/ 7817_UNISDRTerminologyEnglish.pdf, retrieved on 5th March, 2013. 